\section{Dental erosion in the 21st century: what is happening to nutritional habits and lifestyle in our society?}

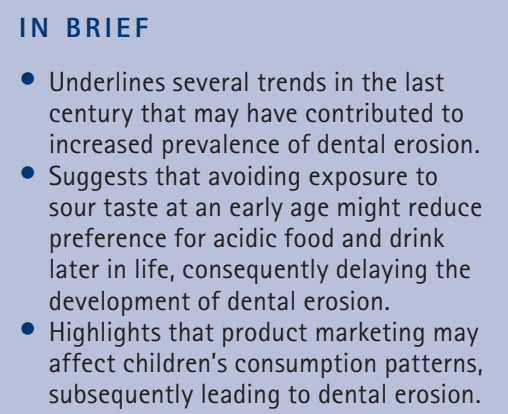

\author{
D. L. Gambon, ${ }^{1}$ H. S. Brand ${ }^{2}$ and E. C. I. Veerman ${ }^{3}$
}

\begin{abstract}
Several developments in Western Europe may have contributed to the increased prevalence of dental erosion during the last decades. Exposing children to sour taste at an early age increases the preference for acidic food and drinks later in life. Acidic fruits and beverages became widely available due to economic prosperity. New types of acidic candies were developed, some of which are kept in the mouth for very long times. Children are exposed to intense marketing of these acidic products, which are widely available in supermarkets and school canteens. In the meantime, much less attention has been paid to the development and marketing of less erosive food products.
\end{abstract}

\section{INTRODUCTION}

As early as 1908, G. V. Black estimated that the prevalence of dental erosion was less than $0.1 \%$. He hypothesised that the origin might be hereditary, but also listed other possible aetiologies from developmental, systemic or extrinsic origin. ${ }^{1}$ In the last 20 years, epidemiological studies showed that a high percentage of young people have signs of dental erosion., ${ }^{2,3}$ The prevalence of erosive tooth wear is still increasing, especially in the younger age groups. ${ }^{4-6}$ The main explanation for this phenomenon is a change in nutritional habits and lifestyle, ${ }^{7,8}$ but what about factors that may have influenced these nutritional habits and lifestyle, like changes in taste preference, increased prosperity and the confectionary industry adding acids to their products?

\section{TASTE PREFERENCE AND CONSUMPTION PATTERNS}

In earlier times, nearly all newborns were breastfed. They got accustomed to the

\footnotetext{
${ }^{1 * B}$ Bambodino Pediatric Dental Clinic, Rotterdam, the Netherlands: ${ }^{2}$ Department of Oral and Maxillofacial Surgery, Academic Centre for Dentistry Amsterdam (ACTA), Amsterdam, the Netherlands: ${ }^{3}$ Department of Periodontology and Oral Biochemistry, Academic Centre for Dentistry Amsterdam (ACTA), Amsterdam, the Netherlands

${ }^{*}$ Correspondence to Dien Gambon

Email: gambon@bambodino.nl; Tel: +31 104334243
}

Accepted 4 May 2012

DOI: 10.1038/sj.bdj.2012.613

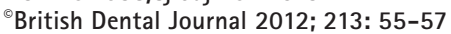

sweet taste of breast milk and toddlers learned to dislike bitter and sour tasting foods and drinks.

In 1887, Charles Darwin had already observed that the sensory world of children differs from that of adults. He noted the strong acceptance of sweet tasting sugars during infancy and childhood, with preference levels decreasing into adult life. ${ }^{9}$ A century later research confirmed the enhanced preference for sweet taste during early development. ${ }^{10}$ Sour preferences increase during childhood and these preferences are related to children's food habits and preferences. ${ }^{11}$

Consumption patterns and preferences of food and beverages in early childhood can influence preferences and nutrient intake at later phases in life. ${ }^{12}$ At the age of 13-14 years, children become much more sensitive to sour tastes and the taste for very sweet food and drinks begins to fade. Children starting consumption of soft drinks at a young age show a higher intake of soft drinks in older age compared to children that start drinking soft drinks later in life. ${ }^{13,14}$

A large study among 8,900 children and young people demonstrated that girls recognise taste much better than boys. Boys needed about 10\% more sourness and 20\% more sweetness to be able to recognise the taste. Girls generally preferred flavours which were not too strong. Boys, on the other hand, tended to like more extreme flavours, giving top marks to the sourest samples, and most preferred a super-sweet soft drink. ${ }^{15}$ So taste perception indicates an age-related increased preference for sour foods and drinks, which may play a role in the development of dental erosion.

As taste preference is related to the consumption of acidic foods, this can provide an explanation as to why dental tissue loss is more frequently observed in males than in females. ${ }^{4,16}$ Progression of tooth loss develops more rapidly in boys than in girls ${ }^{6}$ and the consumption of soft drinks is more popular among boys. Moreover, they have a higher average intake than girls. ${ }^{17}$ Boys also drink more sports drinks and energy drinks., ${ }^{4}$

\section{LEVEL OF PROSPERITY AND CONSUMPTION PATTERN}

In the early twentieth century, the availability of vegetables and fruits was season-dependent and choices were limited to locally and regionally grown products. With the increased level of prosperity in the Western world, a wider variety in food and drinks became available. In particular, since the Second World War, the supply of (acidic) fruit and vegetables has changed dramatically. Products that were once seasonal products in Western Europe, such as tomatoes, citrus fruits, limes, grapes, strawberries, raspberries and pineapples, are now available the whole year. Additionally, new exotic types of 
acidic fruits were introduced such as kiwis and pomegranates.

During the same era, the availability of candy increased dramatically. Many new types and tastes of candies were developed. The caries risk of sugar-containing-candy became well-known. However, many candies also contain organic acid, like citric acid, malic acid and/or fumaric acid, for a fresh taste. These organic acids are potentially erosive for the dental enamel as they can induce a drop in salivary $\mathrm{pH}$. This risk seems especially present in solid hard candies such as lollipops and the so-called 'jawbreakers'. These types of candy slowly melt in the mouth and consumption often takes more than 15 minutes. Consequently, the intra-oral $\mathrm{pH}$ may decrease for a long time to values between 4 and 4.5; a considerable risk for the development of dental erosion. ${ }^{19,20}$ During the last decade, a new type of candy in spray-form has been introduced. These candies, which are directly sprayed onto oral surfaces, have an extremely low $\mathrm{pH}$ of $1.9-2.3 .{ }^{21}$ Some chewing gums are filled with acidic centres, with in vitro erosive effects on human enamel. ${ }^{22}$

\section{SCHOOL CANTEENS}

The increased level of prosperity not only increased the supply and choice of foods and drinks in shops and at home, but affected the amount and type of products available in school canteens. Schools are in a unique position to improve dietary behaviour of juveniles and thereby prevent future health problems like fatness, obesity, ${ }^{23,24}$ diabetes ${ }^{25}$ and dental problems. ${ }^{26,27}$ In some countries sugar-containing beverages have been banned at schools and were replaced by sugar-free alternatives and non-artificially sweetened fruit juices. Although this may have a positive effect on the development of caries and obesity, it seems doubtful whether this will affect the incidence of dental erosion. Sugarcontaining beverages and non-sugar-containing variants do not differ significantly in erosive potential in vitro. ${ }^{28}$

In a recent Dutch study, water coolers were placed in secondary schools, in an attempt to reduce the sales of sugarsweetened beverages. ${ }^{29}$ However, the sales of carbonated beverages in the canteens where the water coolers were placed were not significantly affected. ${ }^{29}$ This indicates that achieving changes in eating and drinking behaviour of children remains a great challenge. Legal regulations on the availability of unhealthy and erosive products in schools might be necessary.

\section{INFLUENCE OF MARKETING}

The increased availability of erosive food products in shops and school canteens is not the only cause responsible for the increased consumption of acidic products and the subsequent development of dental erosion. New food stuffs and soft drinks are marketed aggressively by food advertisements on television, product placement on children's television programmes, advergaming and marketing with toys. Undoubtedly, these advertisements influence children's intake of unhealthy and erosive food and beverages very effectively. ${ }^{30}$ In addition, in supermarkets it is common practice to place sweets just before the tills. Placed at eyeheight of children, many tempted children will try to persuade their parents to buy these products.

\section{HAPPY TOOTH LOGO}

Increasing the knowledge of children and their parents about erosive foods and beverages may affect food choices and subsequently decrease the risk of developing dental erosion. In 1982, the non-profit association Toothfriendly was established in Switzerland. This organisation has developed the Happy Tooth Logo, which might help parents to identify confectionery products that are really tooth friendly (non-cariogenic and non-erosive). Manufacturers who wish to use the Happy Tooth Logo on their product and in advertisements must have their product(s) tested for 'tooth friendliness' at accredited test centres. Until now, however, only very few certified tooth friendly products have appeared on the market. In addition, an inventory in a paediatric dental clinic showed that most children and their parents are unaware of the meaning of the Happy Tooth Logo. Therefore, more attention should be given to available tooth friendly products and more products that are tooth friendly are required.

\section{DEVELOPMENT OF NEW LESS EROSIVE PRODUCTS}

Addition of calcium, phosphate and/or fluoride to erosive drinks and lozenges decreases the critical $\mathrm{pH}$ below which hydroxyapatite dissolves in acid ${ }^{31,32}$ and reduces the enamel softening effects of low $\mathrm{pH}$ sport drinks and juices. ${ }^{28}$ Unfortunately, addition of calcium can influence the taste and new drinks containing smaller amounts of acids are no longer considered to have a fresh taste. Manufacturers of fruit drinks and juices are still looking for other solutions, but even so-called 'less sour fruit drinks' have $\mathrm{pH}$ values below 5.5 .

In the UK, the first commercially available fruit drink with reduced erosive potential was 'Ribena. ${ }^{33}$ In the Netherlands, a similar drink 'Joy' was put on the market in 2004. ${ }^{34}$ This drink disappeared from the market within a few years because children did not like its taste. The selling price, higher than regular erosive drinks, may also have prevented acceptance of this drink by a broad audience.

Development of new products with a less erosive potential has been recommended, but companies mainly seem to invest in the marketing of their currently available erosive products. Since the profits on these foods and beverages are high, companies probably do not feel the need to invest in the development of healthier products, which carry the risk of commercial failure.

\section{CONCLUDING REMARKS}

In the last century, several factors may have contributed to increase the risk of dental erosion in (young) children and adolescents. The increased prosperity, availability of new acidic food products and intense marketing, may all have enhanced the exposure of the paediatric dentition to large amounts of acids at an ever earlier age. However, the exposure of young children to sour taste should be delayed as long as possible. Exposure to sour taste at an early age increases preference for acidic food and drinks later in life, which consequently might increase the risk of developing dental erosion. Therefore, parents and children should receive comprehensive recommendations about eating and drinking habits to prevent erosive tooth wear in children.

1. Black G V. A work on operative dentistry in two volumes. Chicago: Medico-Dental Publishing Company, 1908

2. Bartlett D W, Coward PY, Nikkah C, Wilson R F. The prevalence of tooth wear in a cluster sample of adolescent schoolchildren and its relationship with 
potential explanatory factors. Br Dent J 1998; 184: 125-129.

3. Milosevic A, Young P J, Lennon M A. The prevalence of tooth wear in 14-year-old school children in Liverpool. Community Dent Health 1994; 11: 83-86.

4. Al-Dlaigan $Y H$, Shaw L, Smith A. Dental erosion in a group of British 14-year-old school children. Part I. Prevalence and influence of differing socioeconomic backgrounds. Br Dent J 2001; 190: 145-149

5. Nunn J H, Gordon P H, Morris A J, Pine C M. Walke A. Dental erosion - changing prevalence? A review of British national childrens' surveys. Int J Paediatr Dent 2003; 13: 98-105.

6. El Aidi H, Bronkhorst E M, Huysmans M C, Truin G J. Dynamics of tooth erosion in adolescents: a 3-year longitudinal study. J Dent 2010; 38: 131-137.

7. Cavadini C, Siega-Riz A M, Popkin B M. US adolescent food intake trends from 1965 to 1996. Arch Dis Child 2000; 83: 18-24.

8. O'Sullivan E A, Curzon M E. A comparison of acidic dietary factors in children with and without dental erosion. ASDC J Dent Child 2000; 67: 186-192, 160.

9. Darwin C H. A biographical study of a young child. Kosmos 1877: 1: 367-376.

10. Beauchamp G K, Cowart B J. Development of sweet taste. In Dobbing J (ed) Sweetness. pp 127-138. Berlin: Springer-Verlag, 1987.

11. Liem D G, Mennella J A. Heightened sour preferences during childhood. Chem Senses 2003; 28: 173-180.

12. Skinner J D. Carruth B R, Bounds W. Ziegler P, Reidy $K$. Do food related experiences in the first 2 years of life predict diet variety in school-age children? J Nutr Educ Behav 2002; 34: 310-315.

13. Kvaavik $E_{1}$ Andersen $F L$, Klepp K L. The stability of soft drinks intake from adolescence to adulthood age and the association between long-term consumption of soft drinks and lifestyle factors and body weight. Public Health Nutr 2005; 8: 149-157.

14. Fiorito L M, Marini M, Mitchell D C, SmiciklasWright H, Birch L L. Girls' early sweetened carbonated beverage intake predicts different patterns of beverage and nutrient intake across childhood and adolescence. J Am Diet Assoc 2010; 110: 543-550.

15. Allesen-Holm B H, Frøst M B, Bredie W L P. Taste sensitivity and preferences in Danish school children. In Sensory Science Group Department of Food Science Delegate manual: 8th Pangborn sensory science symposium. 2009. Denmark: University of Copenhagen (KU), 2009.

16. Dugmore $C R$, Rock W P. The prevalence of tooth erosion in 12-year-old children. Br Dent J 2004; 196: 279-282.

17. El Aidi H, Bronkhorst E M, Truin G J. A longitudinal study of tooth erosion in adolescents. J Dent Res 2008; 87: 731-735.

18. Gambon D L, Brand H S, Boutkabout C, Levie D, Veerman E C. Patterns in consumption of potentially erosive beverages among adolescent school children in the Netherlands. Int Dent J 2011; 61: 247-251.

19. Davies R, Hunter L, Loyn T, Rees J. Sour sweets: a new type of erosive challenge? Br Dent J 2008; 204: E3.

20. Brand H S, Gambon D L, Paap A, Bulthuis M S, Veerman E C, Amerongen A V. The erosive potential of lollipops. Int Dent J 2009; 59: 358-362.

21. Gambon D L, Brand H S, Nieuw Amerongen A V. The erosive potential of candy sprays. Br Dent J 2009; 206: E20.

22. Bolan M, Ferreira M C, Vieira R S. Erosive effects of acidic center-filled chewing gum on primary and permanent enamel. J Indian Soc Pedod Prev Dent 2008; 26: 149-152.

23. Ludwig D S, Peterson K E, Gortmaker S L. Relation between consumption of sugar-sweetened drinks and childhood obesity: a prospective, observational analysis. Lancet 2001; 357: 505-508.

24. James J Kerr D. Prevention of childhood obesity by reducing soft drinks. Int J Obes (Lond) 2005; 29: $554-57$

25. Botero D, Wolfsdorf J I. Diabetes mellitus in children and adolescents. Arch Med Res 2005; 36: 281-290.

26. Tahmassebi J F, Duggal M S, Malik-Kotru G, Curzon $M$ E. Soft drinks and dental health: a review of the current literature. J Dent 2006; 34: 2-11.

27. Lee J G, Messer L B. Intake of sweet drinks and sweet treats versus reported and observed caries experience. Eur Arch Paediatr Dent 2010; 11: 5-17.

28. Lussi A, Jaeggi T. Chemical Factors. Monogr Oral SCi 2006; 20: 77-87.

29. Visscher T L, van Hal W C, Blokdijk L, Seidell J C Renders C M, Bemelmans W J. Feasibility and impact of placing water coolers on sales of sugarsweetened beverages in Dutch secondary school canteens. Obes Facts 2010; 3: 109-115.

30. Linn S, Golin J. Beyond commercials: how food marketers target children. Loyola LA Law Rev 2006; 39: 13-32.

31. Jensdottir T, Nauntofte B, Buchwald C, Bardow A. Effects of calcium on the erosive potential of acidic candies in saliva. Caries Res 2007; 41: 68-73.

32. Dawes $\mathrm{C}$. What is the critical $\mathrm{pH}$ and why does a tooth dissolve in acid? J Can Dent Assoc 2003; 69: 722-724.

33. Hughes J A, West N X, Parker D M. Development and evaluation of a low erosive blackcurrant juice drink. 3. Final drink and concentrate, formulae comparisons in situ and overview of the concept. J Dent 1999; 27: 345-350.

34. Huysmans M C, Voss H P, Ruben J L, Jager D J, Vieira A. Erosion effect of a newly developed soft drink. Ned Tijdschr Tandheelkd 2006; 113: 50-55. 